\title{
AWARENESS, ATTITUDES AND PURCHASE OF FOOD WITH QUALITY LABELS IN SLOVENIA
}

\section{SVJESNOST, STAVOVI I KUPOVINA HRANE S OZNAKAMA KVALITETE U SLOVENIJI}

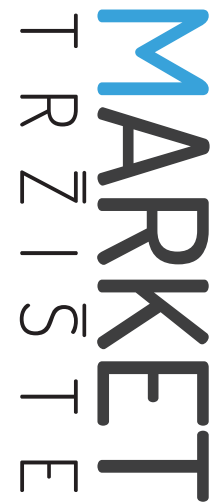

\author{
Market-Tržište \\ Vol. 33, No. 2, 2021, pp. 205-219 \\ UDK 658.89:338.518:641(497.4) \\ DOl http://dx.doi.org/10.22598/mt/2021.33.2.205 \\ Preliminary communication
}

\section{Sabina Krsnik ${ }^{a}$, Karmen Erjavec ${ }^{b}$}

a University of Novo mesto, Faculty of Economic and Informatics, Na Loko 2, 8000 Novo mesto, SLOVENIA, e-mail: sabina. krsnik@uni-nm.si

b University of Novo mesto, Faculty of Economic and Informatics, Na Loko 2, 8000 Novo mesto, SLOVENIA, e-mail: karmen. erjavec@uni-nm.si

\begin{abstract}
Purpose - This study aims to identify the awareness of Slovenian consumers and their attitudes towards labels, as well as the reasons why consumers do not buy labeled food.

Design/Methodology/Approach - A qualitative approach involving six focus groups $(\mathrm{N}=60)$ and shopping with consumers $(\mathrm{N}=16)$ was conducted in the winter of $2020 / 2021$. Thematic analysis was used to analyze the data.

Findings and implications - The results show that the awareness of quality labels is weak mainly due to their considerable number and poor designed, but also on account of ineffective communication campaigns. With respect to the awareness of and attitude to the quality scheme, the participants were divided into four groups: "The Aware", "The Sceptics"', " "Potential Buyers", and "The Disinterested". The reasons for not buying quality labeled foods despite being aware of the labels included overpriced products, no availability of labeled foods generally and those with a good taste and special nutritional value specifically, familiarity/experience with the product, and mistrust of the labeling and social system. The study stresses the important role of social perception and trust in the social system for the acceptance and purchase of such food.
\end{abstract}

\section{Sažetak}

Svrha - Cilj studije je identificirati svjesnost slovenskih potrošača, njihove stavove prema oznakama kvalitete i razloge zašto ne kupuju označenu hranu.

Metodološki pristup - Provedeno je kvalitativno istraživanje sa šest fokus grupa $(\mathrm{N}=60)$ i tijekom kupovine s potrošačima ( $N=16)$ u zimi 2020./2021. Za analizu podataka korištena je tematska analiza.

Rezultati i implikacije - Rezultati pokazuju da je svjesnost o oznakama kvalitete slaba uglavnom zbog činjenice da ih ima izuzetno puno, loše su osmišljene i zbog neučinkovitosti komunikacijskih kampanji. S obzirom na svjesnost i stav prema kvaliteti, sudionici istraživanja su podijeljeni u četiri skupine: "Svjesni", "Skeptici”, "Potencijalni kupci" i "Nezainteresirani". Razlozi zbog kojih se ne kupuje hrana s oznakom kvalitete, usprkos svjesnosti o oznakama, jesu precijenjeni proizvodi i nedostatak dostupnosti hrane s oznakama općenito, a posebno zbog dobrog okusa i posebnih nutritivnih vrijednosti, poznavanja/iskustva s proizvodom i nepovjerenja u označavanje i društveni sustav. Za kupovinu i prihvaćanje takve hrane studija naglašava važnu ulogu društvene percepcije i povjerenja u društveni sustav.

Ograničenja - Glavno ograničenje istraživanja jest u tome što je usmjereno na digitalno pismene potrošače. 
Limitations - The main limitation of the study is its focus on digitally literate consumers only.

Originality - The relevant literature is enhanced by considering the shopping with consumers exercise given that no published study to date, according to the authors' knowledge, is based on the observation of quality labels at the time of purchase.

Keywords - food products label, local food, quality scheme shopping with consumers, focus groups
Doprinos - Relevantna literatura obogaćena je razmatranjem kupovine s potrošačima s obzirom na to da se ni jedna do danas objavljena studija, prema saznanjima autora, ne temelji na promatranju oznaka kvalitete u trenutku kupovine.

Ključne riječi - oznake prehrambenih proizvoda, lokalna hrana, shema kvalitete tijekom kupovine s potrošačima, fokus grupe 


\section{INTRODUCTION}

Quality labels were introduced to both assist consumers in their decision-making and as a means of food control because the presence of a label ensures that the product is traceable to a production area and/or the application of a certain set of skills and know-how (Grunert \& Aachmann, 2016). Growing demand for traditional and local food products (Almli, Verbeke, Vanhonacker, Næs \& Hersleth, 2011; Guerrero, Claret, Verbeke, Enderli, Zakowska-Biemans \& Vanhonacker, 2010; Kühne, Vanhonacker, Gellynck \& Verbeke, 2010) has led food producers across Europe to discuss the use of quality labels as a potentially useful tool for marketing. Similarly, government institutions wish to know whether quality labels provide valuable support for consumers in deciding whether to make a purchase or not. However, both groups are interested in finding out whether quality labels influence the purchase of such food (Grunert \& Aachmann, 2016). The key prerequisite for quality labels to influence the choice and purchase of labeled foods is awareness and knowledge about them (Verbeke, Pieniak, Guerrero \& Hersleth, 2012).

There are different types of quality labels. In contrast to general quality labels, which represent all quality characteristics of the product, specific quality labels focus only on certain quality characteristics, guaranteeing quality, safety, product origin, organic production, etc. In addition to international labels, each country has its own national and/or regional quality labels that are relevant only in a specific country or region (Velčovská \& del Chiappa, 2015).

Central and Eastern European countries like Slovenia, which has 2 million inhabitants, do not have a strong tradition in quality schemes with numerous labels (Kos Skubic, Klopčič, Ule \& Erjavec, 2017; Kos Skubic, Erjavec \& Klopčič, 2018, 2019). In addition to a large and rising number of private labels, the Slovenian government has developed a system of quality schemes over the past 20 years with a quality label collection that includes 11 labels, four EU labels (Organic Farm- ing, Protected Designation of Origin - PDO, Protected Geographical Indication - PGI, and Traditional Specialty Guaranteed - TSG) and seven national labels (Organic Farming, Selected Quality-Slovenia, Slovenian PDO, Slovenian PGI, Slovenian TSG, Higher Quality and Integrated Production). However, the proliferation of labels raises the question of awareness of such labels because their sheer number may lead to consumer confusion (Newsome et al., 2014; Wilson, Rickard, Saputo \& Ho, 2017).

The results of previous research indicate a low level of awareness and knowledge about quality schemes among Slovenian consumers (e.g., Erhart, Juvančič \& Baranja, 2008; Kuhar et al., 2008; Klopčič, Verhees, Kuipers \& Kos Skubic, 2013; Kos Skubic et al., 2017, 2018, 2019) as well as European ones (European Commission, 2013; Eurobarometer, 2020; Grunert \& Aachmann, 2016; Verbeke et al., 2012), as confirmed by literature review (Grunert \& Aachmann, 2016; Evaluating EU food quality schemes, 2020). Eurobarometer (2020) shows that Slovenians have extremely positive attitudes to local food compared to the EU average, standing around the $\mathrm{EU}$ average on their attitudes to quality labels. The question then is how it is possible that Slovenians hold positive views on local food and quality schemes while also having one of the lowest awareness levels of quality labels in Europe, except for Organic Farming on which their awareness is the highest (Kos Skubic et al., 2017, 2018, 2019; Eurobarometer, 2020). Previous research applied a quantitative approach to analyze consumer awareness, knowledge, and attitudes to quality schemes, which leads to querying whether a more indepth approach would yield different results.

The authors of a recent EU study on attitudes to labeled food simply assume that, while being aware of quality labels, consumers do not buy such labeled food for several reasons, including lack of awareness of labels while buying food, overpriced labeled products, and the lack of availability of such food (Evaluating EU food quality schemes, 2020). This begs the question 


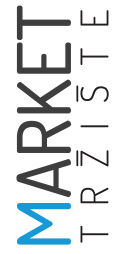

about the real reasons why for such labeled food is not purchased.

This study attempted to uncover these reasons through focus groups and "shopping with consumers." Focus group interviews provide greater insight into the subject matter being analyzed than surveys while also covering a larger number of participants than in-depth interviews (Cohen \& Brooke, 2004). Shopping with consumers is useful not only for verifying the data emerging from focus groups but also to establish the actual perception and use of labels in real-life shopping situations, given that no published study we are aware of has been based on the observation of labels at the time of the actual purchase decision (Grunert \& Aachmann, 2016; Chen \& Antonelli, 2020). Therefore, the aim of this study is to employ combined methods to examine Slovenian consumers' awareness and their attitude to quality labels and why they do not buy such labeled food products.

\section{REVIEW OF LITERATURE}

Quality labels are an important way of communicating the attributes of food products and processes, reducing the asymmetry of consumer information, and facilitating informed consumer choices (Verbeke et al., 2012). Quality labels have many effects, such as the "halo effect": the positive attribute of a food indicated on the label stimulates another attribute in the consumer (Carpenter \& Larcenaux, 2008; Resano, Sanjuan \& Albisu, 2007).

A review of the literature on the use of EU quality labels shows the awareness of EU quality labels in Europe to be generally so low that consumers do not even perceive the presence of such labels while shopping (e.g., Grunert \& Aachmann, 2016; Chen \& Antonelli, 2020; Evaluating EU food quality schemes, 2020). According to the latest Eurobarometer survey (2020), the awareness of EU quality labels is the highest when it comes to the EU Organic farming label (56\%) while standing at just 20\% for the PGl label and 14\% for the PDO and TSG labels. Significant differences across countries and EU quality labels have been found. The Organic Farming logo is the most recognized in Latvia and Lithuania (both 73\%) and Slovenia (72\%), and the least recognized in Malta (30\%). The highest share of respondents in Spain (31\%), France (29\%), and Portugal and Italy (both at 27\%) are aware of the PGI label, whereas Slovenia has one of the lowest shares of respondents aware of this label (16\%). PDO was the most recognized label in Portugal and Slovakia (both 24\%) and the least known in Estonia, Latvia, and the Netherlands (all 3\%), with Slovenian respondents in the middle (12\%). The TSG label was the best recognized in Portugal in Slovakia (24\%), France (23\%), and Italy (21\%), with Slovenia ranking in the middle (12\%), while in the Netherlands (5\%), Finland, Denmark, and Sweden (all at 6\%) that label was the least known (Eurobarometer, 2020).

A European study (Evaluating EU food quality schemes, 2020) conducted in Norway, Germany, Hungary, the UK, Italy, France, and Serbia confirmed the Eurobarometer (2020) finding that Southern European countries have higher levels of knowledge and awareness but that consumers there are less familiar with EU quality labels than they are with national labels. This is related to the more widespread development of EU food quality schemes in these countries and the stronger consumer interest in the specific characteristics of products and processes involved. Taste was the most important driver of food-purchasing decisions in most countries; origin was particularly relevant for consumers in Italy and France while purchasing food while proving to be less important in the countries such as Serbia, the UK, Norway, and Hungary.

Quantitative studies on consumer awareness and the use of European and national quality labels in Central and Eastern European countries also found the awareness of food quality labels to be low. When it comes to national labels, awareness and credibility were higher (Velčovská, 2012; Pinna, Velčovská \& Chiappa 2014; Velčovská \& Sadílek, 2014; Velčovska \& Del 
Chiappa, 2015; Kos Skubic et al., 2017, 2018, 2019; Tomáš, 2020). Price and the trade-off between price and quality were found to be important parameters in consumer choice, followed by taste, origin, experience/familiarity with the product, and its positive effects on health (Horska, Ürgeová \& Prokeinová, 2011; Velčovska \& Del Chiappa, 2015; Tomáš, 2020).

Authors in Central and Eastern Europe agree that consumer trust in quality labels and regulatory implementation are the key determinants of food label choice (e.g., Dolgopolova, Teuber \& Bruschi, 2015; Velčovska \& Del Chiappa, 2015; Kos Skubic et al., 2017, 2018, 2019; Borda, Mihalache, Dumitraşcu, Gafițianu \& Nicolau, 2021). For example, Velčovska and Del Chiappa (2015) found that the main factor of unwillingness to pay for food bearing quality labels is the lack of trust that the products certified truly have the declared properties. Dolgopolova et al. (2015) demonstrated that trust in the food system is embedded in the socio-cultural and historical context. The deeper culturally embedded and widespread mistrust of formal institutions in Russia leads to a high level of mistrust of food bearing any labels, because consumers perceive tradition as providing the main guarantee of healthy food. A recent Polish study (Barska \& Wojciechowska-Solis, 2020) showed the future growth of food markets to be highly dependent on the ability of the food industry and government institutions to gain consumer trust and establish new institutional solutions that guarantee food quality in a credible way.

In Slovenia, food purchasing is an important social issue and trust in social authorities plays a significant role in food acceptance and purchasing behavior (Pejic, Gorenak \& Orthaber, 2013; Klopčič, Slokan \& Erjavec, 2020). Food labeling manipulations and other food safety incidents have reduced the already low trust in social authorities in general, as well as in the political and economic system (Godina, 2016). Thus, the question is: What is the awareness, attitudes, and buying habits of Slovenian consumers in the setting of a weak tradition in quality schemes and considerable mistrust of social authorities in quality labels? We assume that such mistrust of social authorities is one of the main reasons, besides overpriced labeled food, why consumers prefer not to not buy labeled food.

\section{RESEARCH METHODOLOGY}

A qualitative approach with focus group interviews and a shopping with consumers exercise, also known as "go-along" interviews, was applied. First, we conducted focus groups, as a useful method for gathering in-depth opinions and views from several people on a topic that is not so well researched (Rubin \& Rubin, 2005), such as attitudes to quality labels.

The aim of the focus groups was to determine consumers' awareness of and attitudes to quality schemes in respect of the following issues: awareness of quality scheme labels, knowledge of quality labels, attitudes to quality schemes, incentives, and barriers to purchasing food with quality labels, and willingness to pay (more) for food products bearing quality labels. Consumers were selected by the snowball method according to gender (half men and half women), age (up to 25 years, 26-35 years, 36-45 years, 46-55 years, 56-65 years, over 66 years), education, social standard, and place of residence (rural/urban). There were 10 participants in each group, bringing the total to 60 participants. The qualification for participation was not being professionally involved in food-related activities. Six focus groups were conducted in December 2020 and January 2021 using the Microsoft Teams application because it was impossible to conduct them directly in the group on account of the measure introduced in response to COVID-19. The focus groups lasted around 120 minutes, they were recorded, and participants' statements were transcribed.

Second, we conducted "shopping with consumers", which is a qualitative, contextual method that combines observation and in-depth interviews and has become popular for the anal-
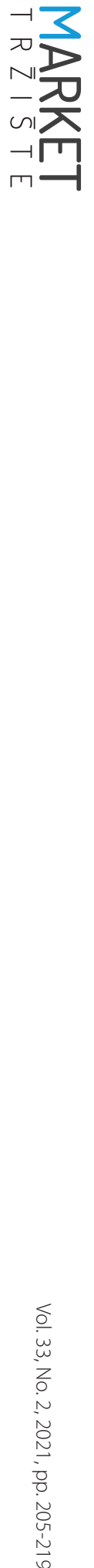


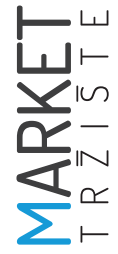

ysis of consumers' shopping habits over the last decade. The advantage of this method is that it taps into participants' direct experience in the retail environment and insights into a situation they do not know or could only reveal in an interview, e.g., self-evident routines the research participants are themselves also unaware of (Silberer \& Wang, 2010). The aim of the shopping with consumers was to verify focus group findings and identify the reasons for not purchasing such labeled foods.

Participants were selected based on the results of the focus groups (belonging to specific groups) and according to the same demographic characteristics: gender (half men and half women), all age groups (up to 25 years, 26-35 years, 36-45 years, $46-55$ years, 56-65 years, over 66 years), different levels of education, social standard, and place of residence (rural/urban), with a total of 16 participants.

The shopping with consumers exercise was conducted in January and February 2021. The time and particular grocery store in which to do shopping were chosen by the participants. We observed the participants while shopping (how they chose the food) and, at the same time, they explained the reasons for choosing a particular food. If a locally produced or labeled food was also available but not chosen by the participants, we asked them why they did not choose the unlabeled food. We considered the measures imposed to prevent the spread of the COVID-19 infection. Shopping lasted for an average of 1 hour. At the time of shopping, we took photos, recorded the conversation and/or reported observations and answers to questions.

The data were analyzed using thematic analysis, as the most common type of analysis for qualitative data used to find common patterns in a database (Rubin \& Rubin, 2005). The coding process was undertaken to identify key themes. Causal patterns and relationships between and within themes were identified to reveal similarities, differences, and contradictions. Four groups of participants were identified according to the theme they represented. Then an ad- ditional thematic analysis of data on shopping with consumers was performed. These results were compared with those of the focus groups to produce final results formulated in a coherent narrative that included quotes from the analyzed transcript. The analysis was conducted by both researchers.

\section{RESULTS}

The reason for a low level of awareness lies in the high number and poor design of quality labels (too small, unclear colors and signs). A typical statement comes from Participant 1 (36 years old, university degree, middle standard, urban): "No, I don't know them. Maybe just this ECO logo. ... The signs are absolutely too small and too similar, practically they are the same. They are simply invisible. Even looking at it all on the computer screen now, I'm pretty confused." Another reason reported for the low level of awareness by the majority of respondents was the ineffective communication campaign for quality schemes. The respondents said they had noticed an advertisement somewhere, but it seemed outdated to most: "Yes, I think I saw an advertisement for this logo somewhere, but I don't know where. I'm not well informed, though l'd like to be. They should really be better promoted," said Participant 2 (49 years old, secondary school education, low standard, urban).

Among the most recognized labels were the national Selected Quality label and the EU Organic Farming label. This can be explained by the participants' statements that both labels are visually the most noticeable among all quality labels and that "the green label with the EU stars is easily recognizable as the EU Organic label," as Participant 3 (63 years old, university degree, high standard, urban) stated. The form of the label is an important factor for identification. When considering the (re)introduction of quality labels, special attention must be paid to the form of the labels.

The analysis of the shopping with consumers exercise showed no confirmation of the declared special importance of local tradition, origin of 
food, and willingness to buy food with quality labels during the food shopping because the participants did not pay attention to Slovenian/ local origin and quality labels. This means that the combination of different methods proved valuable, with the fact the statements were verified by actual buying behavior being of considerable importance for the validity of the results.

Participants expressed their positive attitude to local/national origin and quality schemes due to social pressure to value food of Slovenian origin. They admitted that their focus group statement had been "based on the media message about the importance of local and traditional foods," as stated typically by Participant 4 (27 years old, student, middle standard, urban). The reasons for not buying labeled food lay in overpriced labeled products, lack of availability of food generally and, especially, that with a good taste and special nutritional value, familiarity/experience with the product, mistrust in the labeling system.

According to their awareness, knowledge of, and attitude to the quality scheme, participants were divided into four groups: "The Aware", "The Sceptics", "Potential buyers", and "The Disinterested" (Table 1).

TABLE 1: Examples of the main rationale used by different consumers groups

\begin{tabular}{|l|l|l|}
\hline $\begin{array}{l}\text { Consumer } \\
\text { groups }\end{array}$ & Consumers' main rationale & Discourse extracts \\
\hline Aware & $\begin{array}{l}\text { They recognize the quality labels. } \\
\text { They know about quality labels and the } \\
\text { quality label scheme from high school. } \\
\text { The origin is very important for them. } \\
\text { They do not buy food with quality labels } \\
\text { or local food because it is too expensive, } \\
\text { has no special taste or nutritional value. }\end{array}$ & $\begin{array}{l}\text { "Of course, I know the labels on food. } \\
\text { Wood is important for me, but it's too } \\
\text { expensive and has little protein. This } \\
\text { yoghurt, for example. I do not buy it." }\end{array}$ \\
\hline Sceptics & $\begin{array}{l}\text { They do not recognize or know about } \\
\text { quality labels and the quality scheme. } \\
\text { They are not willing to learn about it or } \\
\text { buy labeled food because they do not } \\
\text { trust the labeling system, the whole food } \\
\text { chain, the various social actors and insti- } \\
\text { tutions, and the system as a whole. }\end{array}$ & $\begin{array}{l}\text { and please do not explain it to me, be- } \\
\text { cause it's all a manipulation. You know, } \\
\text { everyone manipulates in this system: } \\
\text { the farmers, this quality label system, } \\
\text { industry, trade, politics, banks, every- } \\
\text { one." }\end{array}$ \\
\hline $\begin{array}{l}\text { Potential } \\
\text { buyers }\end{array}$ & $\begin{array}{l}\text { They know nothing about quality labels, } \\
\text { but they were willing to learn about quali- } \\
\text { ty schemes and possibly buy such labeled } \\
\text { food or food from the region if it is not } \\
\text { too expensive, tastes good and has cer- } \\
\text { tain desirable nutritional value. }\end{array}$ & $\begin{array}{l}\text { like to know more about the quality } \\
\text { scheme. ... I have to tell you that good } \\
\text { taste and price are important to me. If } \\
\text { a local certified food is reduced in price, } \\
\text { I would buy it, but not at full price. For } \\
\text { that price, it must have less carbohy- } \\
\text { drates and more protein." }\end{array}$ \\
\hline Disinterested & $\begin{array}{l}\text { They are not interested in the quality } \\
\text { scheme in general or in local food be- } \\
\text { cause they only buy what they are used to } \\
\text { and what they like, or they have no time } \\
\text { to deal with quality labels. }\end{array}$ & $\begin{array}{l}\text { "Do not ask me anything. I have no } \\
\text { time. I buy what is cheap and what I am } \\
\text { used to, what my children like to eat." }\end{array}$ \\
\hline
\end{tabular}




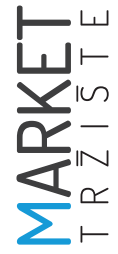

\subsection{Aware participants}

A small group of young focus group participants (6 of them, representing 10\% of the participants) recognized quality labels and had knowledge about quality schemes in Slovenia, which they had acquired at certain secondary schools when they were learning about food classification: "Yes, I know them all, we had to know them while we were learning about categorizing sales of food products at secondary business school" (Participant 5, 21 years old, student, low standard, rural). Knowledge of quality schemes did not influence their food purchases because the price, taste, and nutritional value of food (less sugar and carbohydrates, more protein) were the most important purchase factors. Accordingly, taste was identified as an important factor, but not the most important driver of food-purchase decisions, as found in the Evaluating EU food quality schemes study (2020).

Members of this focus group stressed that origin (local or Slovenian food) is very important for them, yet were unwilling to pay more for food with quality labels: "I trust the quality schemes, but they are much more expensive than other products and I am not willing to pay so much for them when I can get similar good quality for less money," said Participant 6 (23 years old, secondary school degree, middle standard, rural). They also argued that the biggest incentive to buy would be a lower price. For example, Participant 7, a 20-year-old student, said: "The price of local quality food should be lower because the transport costs are lower." The statement was agreed with by Participant 8 (27 years old, student, middle standard, urban), who had good knowledge of quality schemes and said that, while Slovenian origin is important to her, she did not pay attention to it while shopping due to her focus on the price, nutritional value (more protein, less sugar and carbohydrates), and taste:

Interviewer: I saw that you did not pay attention to the quality labels and Slovenian origin when you were deciding to buy. Why is that, given that you told me that this is important to you?
Participant 8: Yes, it is important, I know, all the media is full of this information but, for me, they are too expensive. I'm not willing to overpay for this fruit that doesn't taste anything special or different than cheaper fruit. If it had a discount, I would definitely buy it, it would have an advantage ... But it doesn't.

Interviewer: What if you buy food for special occasions when price is not that important?

Participant 8: No, because they don't have a nice taste or more protein, which I need for my body.

\subsection{Potential buyers}

The group containing about $40 \%$ of the participants did not know and had no knowledge about the labels but, unlike The Sceptics and The Disinterested, they were willing to learn about quality schemes and possibly buy such labeled foods. "I don't know any of these labels. Obviously, I don't follow them, I feel like I'm seeing them for the first time, but I'm interested to know [about labeled food] and it is possible [that I may] buy such food," said Participant 9 (38 years old, university degree, middle standard, rural). A few recognized the "Selected Quality-Slovenia" and "Organic Farming" quality labels because of the familiar form of the label, yet they had no knowledge about them. They named them but could not describe exactly what they meant. For example, "I know Selected Quality, I've seen them on ads. I like the smiley face on the logo. But I don't know exactly what it means" (Participant 10, 73 years old, master's degree, high standard, urban).

This group of participants said that they are willing to be informed about quality schemes but considered them unrecognizable and thought that there are too many of them. Participant 11 (29 years old, university degree, middle standard, urban) declared: "Unless you're someone who really inspects the packet, I think they are really not conspicuous enough. They should be different so we can instantly recognize them."

The group may be divided into two subgroups that vary with respect to the role of the price in 
food purchases. The first group said they would be willing to buy food at the price offered if they had sufficient information, while the second group outlined the cost - which would have to be the same as cheaper, conventional food - as the only incentive.

Members of the first group, dominated by the middle and older generations with a high education level and middle and higher social standard, indicated that the price of food products is not important to them. A typical statement comes from Participant 12 (73 years old, PhD, high standard, urban), who argued that he was willing to buy such labeled food, irrespective of the price, if he were sufficiently informed about the quality schemes. furthermore, this focus group indicated they are willing to pay 20\% more for meat carrying the Organic Farming label and for fruit with the Select Quality-Slovenia label because meat is important to them, and they do not wish to buy "artificial" and "unripe" fruit. For example, "Yes, it is important to me that meat is organic, and I also want to eat fruit from Slovenia and not artificial fruit from South America, so I would pay 20\% more," said Participant 13 (35 years old, PhD degree, higher standard, urban).

The majority of participants reported the unavailability of food bearing quality labels in general as a reason for not buying such labeled food: "I buy what I'm used to because there's not enough labeled food ... I don't have a sufficient food choice. So, I don't have experience with it," said Participant 14 (49 years old, PhD, middle standard, rural). This points to the important role of ensuring that a wide assortment of labeled products is available in grocery stores. In Slovenia, there is a relatively small number of certified food products. Data from EC geographical indicators register shows only 24 registered products with quality labels, of which 8 are PDO, 13 PGI and 3 TSG. Slovenian data from the Ministry of Agriculture also include the national quality scheme "Designation of Higher Quality", which currently includes 5 products (European Commission, 2020).
Shopping with the consumers revealed the unavailability of labeled Slovenian foods with a good taste as another reason for their not buying labeled food. A participant who had learned about quality labels during the focus group even said she intentionally buys French food for special occasions due to its nice taste: "Why didn't I buy labeled food? Because Slovenian food does not taste good. Don't be surprised. This is a wellknown fact. Yes, I buy Slovenian food products for every day, but not for Sundays or special occasions. Slovenian food doesn't taste as good as French food, especially delicatessen item" (Participant 15, 63 years old, masters' degree, high standard, urban). Slovenian consumers still generally believe that the Slovenian market does not offer (enough) food products with a good taste, as the Slovenian tradition is mainly based on peasant dishes that are good for daily consumption, and must therefore be relatively cheap, but are not fit for special occasions (Kos et al., 2017).

Participants also did not buy labeled food products because they did not contain certain desirable nutritional qualities, with higher protein content and less sugar. This was desired by participants of different ages for whom health and being in good psycho-physical condition are extremely important. A typical statement came from Participant 16 (61 years old, PhD, middle standard, urban):

Okay, you got me there. I don't look at labeled foods. I will buy this protein bar. It looks good ... It doesn't have many additives ... But you know why I need it? Because when the devil comes for me, I need to eat protein and not sugar in chocolate because otherwise I'll croak. It's better for the muscles and it's healthier.... You know, like everyone, I don't want to gain weight. In addition, I also need it for good concentration at work so that I do not get so tired.

The above statement refers to the trend of purchasing functional foods with ingredients that provide health benefits beyond their nutritional value, which have become increasingly popular in Europe in recent years (Özen, Bibiloni, Pons 


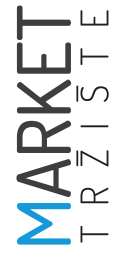

\& Tur, 2014). Following the findings of Zia and Sumbal (2019), many consumers, regardless of gender and age, nowadays buy functional food in order to maintain physical and psychological fitness for various reasons, such as having a good physical appearance (muscular body) or being well focused for effective work. Indeed, finding it difficult to control their external environment, such as precarious employment or the COVID-19 pandemic, they focus on internal factors to stay physically and mentally fit. For the second subgroup of participants, which includes all generations but is dominated by participants with a lower and middle social standard, the most important purchasing factor is price, although they also stress the importance of origin. They mostly buy what is on sale and, within the range of discounted food products, choose what is appropriate in terms of health, taste, and local origin. Familiarity/experience with the product is not as important for this group as it is for the first group because they buy according to price. When they buy cheap yet also healthy and locally grown food, they feel rewarded:

While buying food, taste and price are important to me. If a local, certified food was reduced in price, I would buy it, but not at full price. But if it's cheap and Slovenian, I feel good, I'm kind of happy because I'm being doubly rewarded.... You ask me why? Because I bought cheap and what is socially desirable. (Participant 17, 29 years old, university degree, middle standard, rural)

\subsection{Disinterested participants}

A small group of participants of different ages, education, and standards (about 10\%) indicated they were not interested in the quality scheme in general for various reasons. Older participants were not interested in this topic because they only buy what they are used to and what they like in terms of taste. Some women are not interested because they are (over)burdened and have no time to deal with things other than buying the best quality at the lowest price.
Some students are not interested because their parents buy the food and taste is an important factor in their consumption. Others just do not find the labels and quality schemes relevant: "I don't care if the product has or doesn't have a certificate. There are so many of them," announced Participant 18 (35 years old, university degree, middle standard, urban).

Taste and price are the most important purchasing factors. These factors were mentioned in the conversation but were relatively inactive. "I don't care because I have too much of everything and I get out of the store as fast as I can," said Participant 19 (73 years old, secondary school qualifications, lower standard, rural). The shopping with consumers exercise showed that taste, and familiarity/experience with the food product were the main factors in deciding on the purchase, along with spending as little time as possible in the shop.

\subsection{Sceptics}

A relatively large share of participants (around 40\%) of different ages, education, and standards hold a distinctly negative attitude to quality schemes because they do not trust the labeling system. Urban participants only trust local farmers and buy food that is important to them (e.g., meat) from producers they know personally, such as local farmers or market traders. They mainly buy what they themselves have found to be good or healthy, or what is recommended to them by people they trust. A typical statement is:

What matters is trust. I don't trust any institution. Who certifies and controls it anyway? ... I buy everything on the farm, take the vegetables and fruit they have right then and cook that. They have it for themselves, for their children, so I trust them. ... I trust local farmers within a 5-mile radius. (Participant 20,63 years old, university degree, high standard, urban)

Participants from rural areas do not trust local producers either and mentioned some bad experiences or the experiences of their acquaintances with farmers: "I heard of a case where a 
father and son each have their own farm. The son produces organically, the father conventionally, but they both market and sell products as 'organic'"' (Participant 21, 29 years old, university degree, middle standard, rural).

For these participants, there can be no incentive to buy labeled food since they a priori reject the actions of institutions as much as possible. They also mentioned several details of food manipulations published by the media, namely, that the labels were fake and their main purpose was to mislead people for the sole purpose of increasing profits. For example, Participant 22 (35 years old, secondary school qualifications, lower standard, urban) stated: "Food manipulations are regularly reported in the media. I don't believe in certification and marketing slogans at all. They will write down anything just to sell more and make more money. They all are corrupt, all of them, industry, the state, farmers, the whole system!" This statement also shows the participants do not trust various social actors and institutions or the system as a whole.

\section{DISCUSSION}

The results confirm the results of earlier Slovenian studies (e.g., Erhart et al., 2008; Kuhar et al., 2008; Klopčič et al., 2013; Kos Skubic et al., 2017, 2018, 2019) and European ones (European Commission, 2013; Evaluating EU food quality schemes, 2020; Grunert \& Aachmann, 2016; Verbeke et al., 2012) showing that the awareness of quality labels remains weak. Only a small group of young focus group participants had knowledge of quality schemes which they had acquired at some secondary schools. Other participants were only superficially aware of the most promoted quality schemes but were unable to define them in more detail. Among the most recognized labels were the national Selected Quality label and the EU Organic Farming label, confirming the finding of the Eurobarometer survey (2020) that the level of awareness of the EU Organic Farming label is the highest among Slovenian respondents, even though this con- tradicts the results of other studies showing that national labels are more recognized by Central and Eastern European consumers than EU quality labels (Evaluating EU food quality schemes, 2020; Velčovska \& Del Chiappa, 2015; Kos Skubic et al., 2017, 2018, 2019). This can be explained by the fact that these quality labels were the only labels that were heavily promoted on the Slovenian market.

The analysis showed that the majority of the participants believe quality labels not to be recognizable and too numerous. The fact that poorly designed multiple labels can lead to consumer non-recognition and confusion, so they do not deliver the expected benefits has been confirmed by labeling studies (Newsome et al., 2014; Wilson et al., 2017). The shopping with consumers exercise revealed that participants who had learned about quality schemes during the focus group interviews and stated that they were willing to purchase labeled foods did not pay attention to local/Slovenian origin and quality schemes while actually shopping and also that they did not purchase labeled food due to the overpriced labeled products and unavailability of labeled food generally, as well as food having a good taste and special nutritional qualities specifically, but also on account of their lack of familiarity/experience with the product, and mistrust in the labeling and social system.

One of the main findings of the study is the usefulness of different methods, as the shopping with consumers did not confirm the preference for quality schemes and local/national origin indicated in the focus groups. Therefore, verifying statements with actual purchasing behavior is very important for the validity of the results.

In contrast to consumers in Western Europe, who prioritize taste (Evaluating EU food quality schemes, 2020), price, or a trade-off between price and quality is an important purchasing factor for Central and Eastern European consumers (Horská et al., 2011; Velčovská \& Del Chiappa, 2015). A part of this behavior may be attributed to purchasing power and a part to values. Most Slovenians, like other Central and 


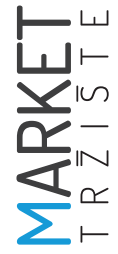

Eastern Europeans, spend a large share of their financial resources on transport and a small share on food (SURS, 2019), meaning that they prioritize external image (including a good car) before food quality.

Some participants said they buy the food products that they are used to and have had good experiences with, which is consistent with the dominant characteristic of the majority of Slovenian consumers, that is, being conservative and sticking to established habits (Mediana, 2020).

The research also showed that most participants believe the Slovenian food in general not to have a fine or exceptional taste so that it can be served on special occasions; consequently, they do not buy it. Namely, Slovenian consumers still generally believe the Slovenian market does not offer (enough) food products with a good taste, as the Slovenian tradition is mainly based on peasant dishes that are good for daily consumption, so they must be relatively cheap, but is not fit for special occasions (Kos Skubic et al., 2017).

Nearly half the respondents have primarily negative views on quality schemes due to mistrust in all links in the food chain and in social institutions such as government agencies. According to the findings of sociologists and anthropologists, the mistrust of quality schemes stems from the fact that many Slovenians do not trust social institutions, including political, governmental, banking, judicial and media organizations, and large companies (Godina, 2016). That mistrust is related to the dissatisfaction of the majority (87\%) of Slovenians with the political system and the political and economic elite, which most Slovenians perceive to be illegitimate, believing that such structures do not allow them to participate in decisions concerning their own lives and only benefit at their expense (Valicon, 2020).

The low level of awareness indicates the ineffectiveness of the communication campaign run for quality schemes by the Slovenian government. This highlights the need for a new and complex communication strategy to promote quality schemes. As McFadden and Lusk (2015) note, traditional advertising and education based on scientific information does not have the expected effect; however, personalized stories and social pressure from influential persons and connections to pressing issues such as climate change might. It is also necessary to promote the good taste of Slovenian food and to pay attention to its nutritional value. Systemic measures are called for to increase the credibility, quality, and transparency of social institutions in Slovenia and other countries in Central and Eastern Europe.

Although we obtained important data about views on quality labels, this research is limited by the fact that it was conducted online due to the protective measures imposed in response to the COVID-19 pandemic. Hence, we could not include in the focus groups elderly people and people of the lowest standard, who have no access to digital technology (computers with cameras) and do not know how to use online conferencing applications. However, we included such people in greater numbers in the second step, the shopping with consumers exercise. The main limitation of the study is that all foods are treated the same, although unpackaged products bought in bulk do not have a quality label and are perceived differently from those with labels. We therefore suggest that future studies consider the difference between packaged and unpackaged food.

\section{CONCLUSION}

The study on the awareness of, attitudes to, and purchase of labeled food showed the usefulness of different methods because shopping with consumers did not confirm the preference for quality schemes and local/national origin indicated in the focus groups. This study contributed to the literature by identifying the reasons why consumers do not buy labeled food products. It demonstrated the usefulness of the shopping with consumers exercise as no pub- 
lished study is based on the observation of quality labels at the time of deciding to purchase.

In Slovenia, a Central-Eastern European country without a strong tradition in quality schemes and with a sea of quality labels, four consumer groups were identified regarding their awareness and knowledge of, and attitude to the quality scheme. These are: "The Aware", a small group of young focus group participants who recognized quality labels and had knowledge of quality schemes they acquired at certain secondary schools; "The Disinterested", who were not interested in quality schemes generally; "The Sceptics", who mistrust farmers and the labeling system because they do not trust social institutions; "Potential buyers", who indicated they are willing to learn about quality schemes, yet did not buy such labeled food even though they were aware of it on account of the over- priced food with quality labels, familiarity/experience with the product, and the lack of labeled Slovenian food in general and especially that with a good taste and special nutritional value.

Thus, this research study highlights the important role of social perception and trust in the social system for the acceptance and purchase of labeled foods on top of its price, habitual/experience with labeled foods, food availability, and taste. The study also shows that the European consumer is not a homogeneous phenomenon, being influenced by socio-cultural factors, income, GDP, and so on.

\section{Funding}

This work was supported by the Slovenian Research Agency under Grant [number V4-2008]; Ministry of Agriculture, Forestry and Food under Grant [number V4-2008].

\section{References}

1. Almli, V. L., Verbeke, W., Vanhonacker, F., Næs, T., \& Hersleth, M. (2011). General image and attribute perceptions of traditional food in six European countries. Food Quality and Preference, 22(1), 129-138.

2. Barska, A., \& Wojciechowska-Solis, J. (2020). E-consumers and local food products: A perspective for developing online shopping for local goods in Poland. Sustainability, 12(12), 4958-4975.

3. Borda, D., Mihalache, O. A., Dumitraşcu, L., Gafițianu, D., \& Nicolau, A. I. (2021). Romanian consumers' food safety knowledge, awareness on certified labelled food and trust in information sources. Food Control, 120, 107544-107555.

4. Carpenter, M., \& Larceneux, F. (2008). Label equity and the effectiveness of values-based labels: an experiment with two French protected geographic indication labels. International Journal of Consumer Studies, 32(4), 499-507.

5. Chen, P-J., \& Antonelli, M. (2020). Conceptual Models of Food Choice: Influential Factors Related to Foods, Individual Differences, and Society. Foods, 9(12), 1898.

6. Cohen, B. H., \& Brooke, L. R. (2004). Essentials of statistics for the social and behavioral sciences. London: Wiley.

7. Dolgopolova, I., Teuber, R., \& Bruschi, V. (2015). Consumers' perceptions of functional foods: trust and food-nephobia in a cross-cultural context. International Journal of Consumer Studies, 39(6), 708-715.

8. Erhart, V., Juvančič L., \& Baranja S. (2008). Spremljanje stanja na trgu izbrane slovenske zaščitene kmetijske pridelke oziroma živila v letu 2008 [Monitoring the Situation on the Market of Selected Slovenian Protected Agricultural Products or Foods in 2008]. Zavod Ekometer.

9. Eurobarometer (2020). Europeans, Agriculture and the CAP. Retrieved from: from https://ec.europa.eu/commfrontoffice/publicopinion/index.cfm/Survey/getSurveyDetail/instruments/special/search/agriculture/surveyKy/2229 
10. European Commission. (2000). Geographical indicators register. Retrieved from: https://ec.europa.eu/info/food-farming-fisheries/food-safety-and quality/certification/quality-labels/geographical-indications-register/

11. European Commission. (2013, December 2). Consumer market study on the functioning of voluntary food labelling schemes for consumers in the European Union EAHC/FWC/2012, 8604. Retrieved from:

12. Evaluating EU food quality schemes. (2020, May 31). Strenght2food. Retrieved from: https:// www.strength2food.eu/2020/05/31/factsheet-4-evaluating-eu-food-quality-schemes-consumers-producers-and-sustainability-perspectives/

13. Godina, V. (2016). Zablode postsocializma [The Delusions of Postsocialism]. Beletrina.

14. Grunert, K. G., \& Aachmann, K. (2016). Consumer reactions to the use of EU quality labels on food products: A review of the literature. Food Control, 59, 178-187.

15. Guerrero, L., Claret, A., Verbeke, W., Enderli, G., Zakowska-Biemans, S., \& Vanhonacker, F. (2010). Perception of traditional food products in six European regions using free word association. Food Quality and Preference, 21, 225-233.

16. Horská, E., Ürgeová, J. \& Prokeinová, R. (2011). Consumers' food choice and quality perception: Comparative analysis of selected Central European countries. Agricultural Economics, 57, 493-499. http://ec.europa.eu/consumers/consumer_evidence/market_studies/food_labelling/index_ en.htm

17. Klopčič, M., Slokan, P., \& Erjavec, K. (2020). Consumer preference for nutrition and health claims: A multi-methodological approach. Food Quality and Preference, 82, 103863-103873.

18. Klopčič, M., Verhees, F. J. H. M., Kuipers, A., \& Kos Skubic, M. (2013). Consumer perception of home made, organic, EU certified, and traditional local products in Slovenia. In: M. Klopčič, A. Kuipers \& J. F. Hocquette (eds.), Consumer attitudes to food quality products, (pp. 179-194). Rome: EAAP publication.

19. Kos Skubic, M., Erjavec, K., \& Klopčič, M. (2018). Consumer preferences regarding national and EU quality labels for cheese, ham and honey. British Food Journal, 120(3), 650-664.

20. Kos Skubic, M., Erjavec, K., \& Klopčič, M. (2019). Consumer awareness of PDO-labelled food in Slovenia. Italian Journal of Animal Science, 18(1), 1-6.

21. Kos Skubic, M., Klopčič, M., Ule, A., \& Erjavec, K. (2017). The food quality labels: Awareness and knowledge of Slovenian consumers. Agro Food Industry Hi-Tech, 28(6), 64-67.

22. Kuhar, A., Juvančič, L., Medved, P., Ogorevc Račič, K., Juvančič, M., \& Kodelja, U. (2008). Tržne možnosti in percipirana vrednost kmetijskih in živilskih proizvodov posebne kakovosti: Končno poročilo o rezultatih opravljenega raziskovalnega dela na projektu v okviru CRP »Konkurenčnost Slovenije 2006-2013. Biotehniška fakulteta.

23. Kühne, B., Vanhonacker, F., Gellynck, X., \& Verbeke, W. (2010). Innovation in traditional food products in Europe: Do sector innovation activities match consumers acceptance? Food Quality and Preference, 21, 629-638.

24. McFadden, B. R., \& Lusk, J. L. (2015). Cognitive Biases in the Assimilation of Scientific Information on Global Warming and Genetically Modified Food. Food Policy, 54, 35-43.

25. Mediana (2020, November 10). Kako slovenci sprejemamo nove stvari? Retrieved from: https:// www.marketingmagazin.si/vpogled/kako-slovenci-sprejemamo-nove-stvari

26. Newsome, R., Balestrini, C. G., Baum, M. D., Corby, J., Fisher, W., Goodburn, K., Labuza, T. P., Prince, G., Thesmar, H. S., \& Yiannas, F. (2014). Applications and Perceptions of Date Labeling of Food. Comprehensive Review in Food Science and Safety, 13(4), 745-769.

27. Özen, A. E., Bibiloni, M., Pons, A., \& Tur, J. A. (2014). Consumption of functional foods in Europe: A systematic review. Nutricion Hospitalaria, 29, 470-478. 
28. Pejic, V., Gorenak, I., \& Orthaber, S. (2013). The role of trust in the food supply chain. Business Logistics in Modern Management, 13, 33-39.

29. Pinna, M., Velčovská, Š., \& Chiappa, G. (2014). The food quality labels: awareness and willingness to pay in the context of Italy. $13^{\text {th }}$ Marketing Trends Congress, Venice (Italy).

30. Resano, H., Sanjuan, A. I., \& Albisu, L. M. (2007). Consumers' acceptability of cured ham in Spain and the influence of information. Food Quality and Preference, 18, 1064-1076.

31. Rubin H. J., \& Rubin, I. S. (2005). Qualitative Interviewing. New York, NY: Sage.

32. Silberer, G., \& Wang, H-H. (2010). Shopping with Consumers « as a research method - Design and results of a shopping behaviour study. Journal of Marketing Trends, 1, 43-50.

33. SURS. (2019, October 8). Gospodinjstva v Sloveniji porabila v 2018 za življenjske potrebščine povprečno 19.560 EUR. Retrieved from: https://www.stat.si/StatWeb/news/Index/8420

34. Tomáš, S. (2020). Examining Attitudes Toward Food Quality Labels: Evidence from Czechia. Journal of Food Products Marketing, 26(3), 197-211.

35. Valicon. (2020, June 18). Ogledalo Slovenije 2020- II. del. Retrieved from: https://www.valicon. net/sl/2020/06/valicon-ogledalo-slovenije-2020-ii/

36. Velčovská, Š. (2012). Food Quality labels and their Perceptions by Consumers in the Czech Republic. International Journal of Social, Educational, Economic, Business and Industrial Engineering, 6, 1047-1052.

37. Velčovská, Š., \& Del Chiappa, G. (2015). The Food Quality Labels: Awareness and Willingness to Pay in the Context of the Czech Republic. Acta Universitatis Agriculturae et Silviculturae Mendelianae Brunensis, 63(2), 647-658.

38. Velčovská, Š., \& Sadílek, T. (2014). Analysis of quality labels included in the European Union quality schemes. Czech Journal of Food Science, 32, 194-203.

39. Verbeke, W., Pieniak, Z., Guerrero L., \& Hersleth, H. (2012). Consumer's awareness and attitudinal determinants of European union quality label use on traditional foods. Bio-Based and Applied Economics, 2(2), 213-229.

40. Wilson, N. L. W., Rickard, B. J., Saputo, R., \& Ho, S-T. (2017). Food Waste: The Role of Date Labels, Package Size, and Product Category. Food Quality and Preference, 55, 35-44.

41. Zia, F., \& Sumbal, S. (2019). Physical Performance and Functional Food. Journal of Human Nutrition and Food Science, 7(1), 1128-1138. 